\title{
Effect of Missing Nutrient Elements on Grain Yield of Wet Season Rice in Bangladesh
}

\author{
Md Mozammel Haque, Abdul Latif Sha, Jatish Chandra Biswas, Md Rafiqul Islam, \\ Aminul Islam, Umme Aminun Naher
}

Soil Science Division, Bangladesh Rice Research Institute, Gazipur, Bangladesh

Email:mhaquesoil@yahoo.com, abidensoil@yahoo.com, jatishb@yahoo.com,rafiqbrri@yahoo.com, aminbrri@gmail.com,naher39@gmail.com

How to cite this paper: Haque, M.M., Sha, A.L., Biswas, J.C., Islam, M.R., Islam, A. and Naher, U.A. (2019) Effect of Missing Nutrient Elements on Grain Yield of Wet Season Rice in Bangladesh. American Journal of Plant Sciences, 10, 631-639. https://doi.org/10.4236/ajps.2019.104046

Received: February 15, 2019

Accepted: April 23, 2019

Published: April 26, 2019

Copyright $\odot 2019$ by author(s) and Scientific Research Publishing Inc. This work is licensed under the Creative Commons Attribution International License (CC BY 4.0).

http://creativecommons.org/licenses/by/4.0/ Open Access

\begin{abstract}
Background and objective: Long-term fertility study is one of the important factors to monitor changes in yield because of different nutrient management options and cropping systems involved in Asian regions. Many short-term and long-term fertilizer trials were conducted for intensive irrigated rice cropping patterns mostly to provide fertilizer rate, but did not considered sustainable soil management for soil health. The objective of the present study was to examine the effect of missing nutrient elements for a long time on rice yield, photosynthetic rate and residual soil fertility. Materials and Methods: The experiment was initiated on a permanent layout at the Bangladesh Rice Research Institute (BRRI) farm, Gazipur during 2000 to 2008 in wet season. Seven treatments in randomized complete block design with four replications were imposed. Grain yield was determined at physiological maturity from three $5 \mathrm{~m}^{2}$ areas within each plot followed by bagging and threshing. Photosynthetic was measure by Li Cor 6400 (USA) machine during study period. Soil sample was analyzed for following standard methods. Results: It was found that grain yield was in decreasing trends for the missing elements that were similar with BR 11 and BRRI dhan 31. On an average, grain yield reductions were $11.6,7.0,10.6,1.1$ and 3.4 percent for $-\mathrm{N},-\mathrm{P},-\mathrm{K}$, $-\mathrm{S}$ and $-\mathrm{Zn}$, than complete fertilizer treatment (NPKSZn) respectively. Under no fertilization, the ability of soil was to produce $2.9 \mathrm{t} \cdot \mathrm{ha}^{-1}$ of BR11 and $3.1 \mathrm{t} \cdot \mathrm{ha}^{-1}$ of BRRI dhan 31 respectively. Photosynthetic rate of rice plant was always higher in complete fertilizer treatment (NPKSZn) than missing of any nutrient element. The decrease in photosynthetic rate was more pronounced with $\mathrm{N}$ missing than others for both the rice varieties. Conclusion: It is concluded that balance chemical fertilizers (NPKSZn) are to be used for sustained and/or increased rice production and to maintain soil fertility.
\end{abstract}

\section{Keywords}

Long-Term, Fertilizer, Soil Nutrient Status, Photosynthetic Rate, Variety, 
Yield Pattern

\section{Introduction}

Rice is the main food for more than 150 million populations in Bangladesh, and it occupies $74 \%$ of the total arable land areas [1]. Newly release rice variety by Rice Research Institute and innovative farming technologies have dramatically increased rice production in Bangladesh from ca. 17 million tons (MT) in 1970 to ca. $48 \mathrm{MT}$ in 2009 , mainly due to introduction of high yielding rice varieties and chemical fertilizers [2] [3], which is not enough for 2050 and beyond. It will require about 44.6 MT milled rice in 2050 to feed about 215.4 million peoples [4]. As the rice productivity of Bangladesh is still low compared to other Asian countries, such as Indonesia and Malaysia [5]; it will be difficult to achieve the target of food self-sufficiency in future.

Rational fertilization and management of soil fertility could be one of the most important measures to improve rice productivity and soil quality because inadequacy of five nutrient elements (NPKSZn) in many paddy soils of Bangladesh is responsible for reaping high yields [6] [7]. In general, missing of one nutrient element from complete fertilization reduced grain yield of rice, but it was reversible when missing nutrients were added [8] [9] [10]. Previous researcher also found that if limiting nutrient is corrected through reverse management in a long-term missing element experiment, rice yields switch back to initial status of complete (NPKSZn) fertilization [11].

There are many mechanisms of yield reduction like reduced spikelet number, 1000-grain weight [12], reduction in photosynthetic rate, etc. Dey and Narasinga Rao [13] reported that deficiency of N, P and $\mathrm{K}$ reduced photosynthetic rate in early rice varieties and ultimately reduced grain yield. Declining rice and wheat productivity with continuous cropping was related to deficiency of $\mathrm{P}, \mathrm{K}, \mathrm{S}$ and Znin Asia including Bangladesh [10] [14] [15]. The relative decrease in rice yield, in absence of a mineral nutrient as compared to an adequate soil fertility level, can give an idea of the magnitude of deficiency. However, no such findings are available based on long-term missing element trials in Bangladesh. Therefore, the objectives of this study were to assess the effect of long-term missing of chemical nutrient sources on rice yield, soil properties, and rice plant photosynthetic rate during wet season.

\section{Materials and Methods}

\subsection{Experimental Site and Season}

A long-term missing element experiment on rice-rice system was conducted at the Bangladesh Rice Research Institute research farm, Gazipur, Bangladesh during wet seasons of 2000-2008. The annual rainfall was about $2000 \mathrm{~mm}$, and about $80 \%$ of rainfall is concentrated during mid June to the end September. The 
soil of the experimental field is Chhiata clay loam, a member of hyperthermic verticendoaquept. The soil was characterized with $\mathrm{pH}\left(1: 5\right.$ with $\left.\mathrm{H}_{2} \mathrm{O}\right) 7.0,12.2$ $\mathrm{g} \cdot \mathrm{kg}^{-1}$ organic carbon, $1.1 \mathrm{~g} \cdot \mathrm{kg}^{-1}$ total $\mathrm{N}, 19 \mathrm{mg} \cdot \mathrm{kg}^{-1}$ available $\mathrm{P}, 70 \mathrm{mg} \cdot \mathrm{kg}^{-1}$ available $\mathrm{K}, 9 \mathrm{mg} \cdot \mathrm{kg}^{-1}$ available $\mathrm{S}$ and $3.3 \mathrm{mg} \cdot \mathrm{kg}^{-1}$ available $\mathrm{Zn}$.

\subsection{Experimental Design and Management}

The treatments were: NPKSZn as complete treatment, omission of one or more nutrients from complete treatment i.e. $-\mathrm{N},-\mathrm{P},-\mathrm{K},-\mathrm{S},-\mathrm{Zn}$, and control that were assigned in a randomized complete block design with four replications. Indicator varieties used were BR11 and BRRI dhan 31. However, decreased yield was calculated from complete treatment yield minus omission nutrient plot yield during the period of 2000-08. The fertilizer rate NPKSZn @ 80-25-35-20-5 $\mathrm{kg} \cdot \mathrm{ha}^{-1}$ was used in T. Aman season. Nitrogen was applied in three 3 equal splits i.e. $1 / 3$ at final land preparation, $1 / 3$ at active tillering stage and 1/3 at $5-7$ days before panicle initiation stage. Rest of the fertilizers was applied at final land preparation. The unit plot size was $6 \mathrm{~m} \times 7.3 \mathrm{~m}$. Thirty-three day-old $2-3$ seedlings in a hill were transplanted during 1 - 15 August in each year.

\subsection{Rice Yield Determination}

Grain yield was determined at physiological maturity from three $5 \mathrm{~m}^{2}$ areas within each plot followed by bagging and threshing. The samples were sun dried for three days, cleaned and weights were recorded in digital balance for every sample followed by moisture measurement by digital grain moisture meter (Satakemoistex, model SS-5). Grain yields were adjusted at @ 14\% (wt.wt $\left.{ }^{-1}\right)$.

\subsection{Soil Sample Collection and Chemical Analysis}

The post-harvest soil samples were collected after $18^{\text {th }}$ crop conditions in rice field. Soil sample was analyzed for following standard methods. Organic carbon was determined by Walkley and Black method [16], total nitrogen by modified Kjeldahl method, available phosphorus by modified Olsen method and exchangeable potassium by ammonium acetate extraction method following the procedures of page et al. [17]. Available sulphur was extracted by 500 ppm P [18]. Available zinc was determined by DTPA extraction method [19].

\subsection{Photosynthetic Rate Determination}

In addition, photosynthesis was measured for T. Aman 2008 ( $18^{\text {th }}$ rice crop) at maximum tillering stage in field condition by Li Cor 6400 (USA) machine in all treatments (seven) during field conditions.

\subsection{Statistical Analysis}

Analysis of variance was performed by using the procedure of GLM to determine the effects of treatment on yield. Means for rice yield was compared by using Tukey's HSD method by using [20] systems. 


\section{Results}

\subsection{Rice Yield at Different T. Aman Varieties}

Long-term varietal yield levels and response behaviors of BR11 and BRRI dhan 31 during T. Aman season were apparently identical. Omission of N, P, K, S and Zn decreased grain yields than complete treatment (NPKSZn) over times but not lower than absolute fertilizer control treatment (Table 1). The reductions in grain yields were almost identical with BR11 and BRRI dhan 31 that varied from $3 \%$ to $12 \%$ depending on missing elements (Table 1). The least response was observed with $\mathrm{Zn}$ missing and the highest with $\mathrm{N}$ missing. The omission of any nutrient element from complete treatment reduced grain yields in both the varieties after $18^{\text {th }}$ crop (Figure 1). In fertilizer control condition i.e. soil ability to produce yield $2.9 \mathrm{t} \cdot \mathrm{ha}^{-1}$ of BR11 after $9^{\text {th }}$ year, but during initial three years it was $3.5 \mathrm{t} \cdot \mathrm{ha}^{-1}$. Similarly, average of first three years yield of complete fertilized treatment (NPKSZn) was 3.77 - $4.43 \mathrm{t} \cdot \mathrm{ha}^{-1}$ depending on varieties (Figure 1).

\subsection{Contribution of Soil and Chemical Fertilizer on Rice Yield}

During 2000-2004, the native soil contribution to yield was about $64 \%$ and that of fertilizer was about $36 \%$. In 2005-2008, contributions of soil and fertilizer were $60 \%$ and $40 \%$, respectively (Figure 2 ).

\subsection{Determination of Photosynthetic Rate}

Photosynthetic rate of rice plant was always higher in complete (NPKSZn) fertilizer treatment than missing of a single nutrient element (Table 2). About 10\% $28 \%$ photosynthetic rate decreased due to nutrient omission like N, P, K and S than complete chemical fertilization. There is no significant difference in photosynthetic rate because of $\mathrm{Zn}$ missing.

\subsection{Changes of Soil Properties}

Continuous rice cultivation without fertilizer application for nine years significantly deteriorated soil $\mathrm{pH}$, organic carbon and inorganic $\mathrm{N}$ and $\mathrm{K}$ (Table 3).

Table 1. Grain yield of rice in complete and omission of single nutrient treatment from 2000-2008.

\begin{tabular}{cccccc}
\hline \multirow{2}{*}{ Treatment } & \multicolumn{2}{c}{ Grain yield $\left(\mathrm{t} \cdot \mathrm{ha}^{-1}\right)$} & \multicolumn{3}{c}{ Percent yield decreased compared to } \\
& NPKSZn treatment & \\
\cline { 2 - 6 } & BR11 & BRRI dhan 31 & BR11 & BRRI dhan 31 & Mean \\
\hline NPKSZn & $3.96 \pm 0.08$ & $3.89 \pm 0.12$ & - & - & - \\
$-\mathrm{N}$ & $3.50 \pm 0.07$ & $3.44 \pm 0.10$ & 11.62 & 11.57 & 11.6 \\
$-\mathrm{P}$ & $3.65 \pm 0.12$ & $3.65 \pm 0.12$ & 7.83 & 6.17 & 7.0 \\
$-\mathrm{K}$ & $3.5 \pm 0.073$ & $3.52 \pm 0.14$ & 11.62 & 9.51 & 10.57 \\
$-\mathrm{S}$ & $3.91 \pm 0.18$ & $3.87 \pm 0.20$ & 1.62 & 0.51 & 1.07 \\
- Zn & $3.82 \pm 0.11$ & $3.76 \pm 0.20$ & 3.54 & 3.34 & 3.44 \\
Control & $3.13 \pm 0.12$ & $3.14 \pm 0.14$ & - & - & - \\
\hline
\end{tabular}




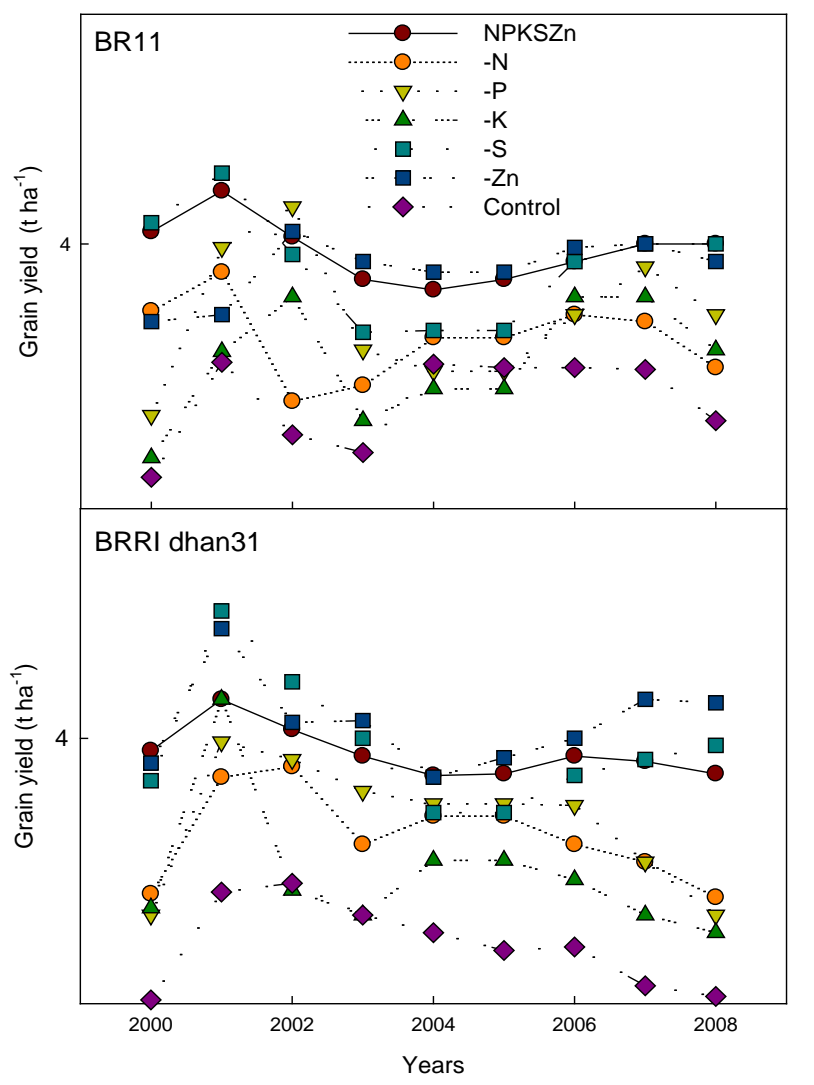

Figure 1. Changes of rice yield during 2000-2008 in T. Aman season.

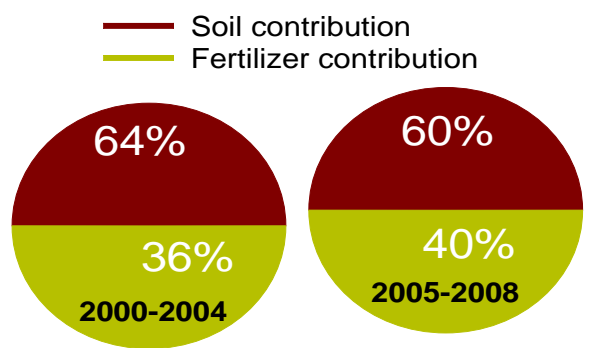

Figure 2. Yield contribution by soil and fertilizer during 2000-2008 in T. Aman.

Moreover, the long-term $\mathrm{P}$ fertilizations significantly increased available $\mathrm{P}$ contents in soil.

\section{Discussion}

Long-term effect of complete fertilization (NPKSZn) and missing of nutrient elements showed variable response to grain yields of rice. Use of complete chemical fertilizer was conducive to maintain and/or improving rice yield than missing of any nutrient element. Since most of our farmers use imbalanced fertilizers [21] for production of crops, nutrient depletion or build up takes place [22] [23] resulting in poor crop yield. These imply that balanced fertilizer should be added for crop production, although rate of fertilizer use needed to be tuned 
Table 2. Photosynthetic rate of rice plant in nutrient stress and sufficient condition at maximum tillering stage during T. Aman season ( $\left.18^{\text {th }} \mathrm{crop}\right)$.

\begin{tabular}{ccc}
\hline \multirow{2}{*}{ Treatment } & \multicolumn{2}{c}{ Photosynthetic rate $\left(\mu \mathrm{mol} \mathrm{CO}_{2} \mathrm{~m}^{-2} \cdot \mathrm{Sec}^{-1}\right)$} \\
\cline { 2 - 3 } & $\mathrm{BR} 11$ & BRR Idhan 31 \\
\hline NPKSZn & 36.13 & 40.23 \\
$-\mathrm{N}$ & 26.03 & 31.07 \\
$-\mathrm{P}$ & 30.73 & 35.87 \\
$-\mathrm{K}$ & 32.63 & 37.90 \\
$-\mathrm{S}$ & 28.23 & 32.93 \\
$-\mathrm{Zn}$ & 36.07 & 36.37 \\
Control & 29.67 & 34.23 \\
$\mathrm{LSD}(0.05)$ & 1.08 & 1.36 \\
$\mathrm{CV}(\%)$ & 1.94 & 2.15 \\
\hline
\end{tabular}

Table 3. Changes of soil nutrients over initial soil due to omission of nutrients after 18 cropping, BRRI-Gazipur.

\begin{tabular}{ccccccc}
\hline \multirow{2}{*}{ Treatment } & $\begin{array}{c}\text { Organic C } \\
(\%)\end{array}$ & Total N $(\%)$ & $\mathrm{P}\left(\mathrm{mg} \cdot \mathrm{kg}^{-1}\right)$ & $\mathrm{K}\left(\mathrm{mg} \cdot \mathrm{kg}^{-1}\right)$ & $\mathrm{S}\left(\mathrm{mg} \cdot \mathrm{kg}^{-1}\right)$ & $\mathrm{Zn}\left(\mathrm{mg} \cdot \mathrm{kg}^{-1}\right)$ \\
\hline NPKSZn & 2.10 & 0.11 & 19 & 55 & 28 & 4.7 \\
$-\mathrm{N}$ & 2.14 & 0.12 & 30 & 47 & 21 & 4.7 \\
$-\mathrm{P}$ & 2.07 & 0.11 & 3 & 47 & 22 & 5.0 \\
$-\mathrm{K}$ & 2.14 & 0.11 & 19 & 43 & 13 & 5.3 \\
$-\mathrm{S}$ & 2.41 & 0.12 & 22 & 47 & 23 & 4.7 \\
- Zn & 2.11 & 0.11 & 18 & 47 & 16 & 1.3 \\
Control & 1.90 & 0.09 & 3 & 43 & 20 & 2.0 \\
Initial soil & 1.97 & 0.08 & 9.8 & 70 & 9 & 3.3 \\
\hline
\end{tabular}

up after certain period of time for a particular cropping sequence. Cassman and Pingali [24] opined that rice cultivation for several consecutive years with constant fertilizer inputs are responsible for declining trend in rice yields. Moreover, Shah et al. [25] obtained higher yield with higher dose of NK than previous recommended dose in Boro season. In other words, continuous rice cultivation with recommended fertilizer dose for long time may not be enough to obtain maximum yield as previous or need to be increased fertilizer dose for obtaining experimental inception yield level.

Organic matter contents in most soils of Bangladesh are poor [9]; so missing of $\mathrm{N}$ reduces grain yield than any other element. On the other hand, many farmers uses $\mathrm{P}$ and $\mathrm{K}$ fertilizers, although not in right proportion [9] [26], yield reductions are low with $\mathrm{P}$ and $\mathrm{K}$ compared to $\mathrm{N}$ missing. Phosphorus fertilization @ $25 \mathrm{~kg} \cdot \mathrm{ha}^{-1} \cdot \mathrm{crop}^{-1}$ was responsible for its build up in soil; but when $\mathrm{P}$ was not applied, its availability in soil decreased in the same way of unfertilized plot. Al- 
though $\mathrm{K}$ fertilizer was applied based on soil test at $35 \mathrm{~kg} \cdot \mathrm{ha}^{-1} \cdot \mathrm{crop}^{-1}$, its balance was negative. Depletion of available $\mathrm{K}$, even in treatments receiving $\mathrm{K}$ fertilization under continuous cropping, was also reported by Subramanian and Kumaraswamy [27]. Our findings and available literatures [23] [28] indicate that $\mathrm{K}$ rate need to be tuned up more frequently to maintain not only soil health but also to improve activity of other nutrients [17]. Sulphur fertilization $\left(20 \mathrm{~kg} \cdot \mathrm{ha}^{-1} \cdot \mathrm{crop}^{-1}\right)$ improved soil available $S$, but its addition rate can be further reduced for rice in regions of industrial development. Higher level of available $S$ in control plot compared to initial soil might be due to wet and dry deposition [29].

Missing a particular nutrient changes nutrient ratios in soil and thus plant suffer from either excess or deficiency resulting in reduced physiological activities [23]. So, we have found variable photosynthetic rate depending on missing elements. Addition of missing nutrient element in reverse management also increased photosynthetic rate of rice plant. The decrease of photosynthesis rate was prominent with $\mathrm{N}$ when omitted from complete treatment causes low supply of $\mathrm{N}$ reduced chlorophyll content in plants [30].

\section{Conclusion}

Continuous rice-rice cropping for a longer period of time even with recommended chemical fertilizer dose may not provide sustainable grain yield because other minor and micro elements are removed from soil, which must come from organic sources. Potassium uptake by rice influences many enzyme activities in plants and thus grain and straw yields. So, special care has to be taken in adjusting $\mathrm{K}$ rate for successful crop production and to maintain soil fertility in Bangladesh. We have considered only five elements in the present investigation that need to be extended for some more nutrients like magnesium, iron, copper, silicon and boron, etc. and addition of organic materials for sustained rice production in Asian countries.

\section{Acknowledgements}

The author gratefully acknowledged the contributions of all Scientist of Soil Science Division, Bangladesh Rice Research Institute, who initiated and conducted the experiment and Mr. Abdullah-Al-Mahbub, Scientific Officer of Plant Physiology division, BRRI Gazipur for taking photosynthesis reading in field condition.

\section{Authors' Contributions}

M.M.H., A.L.S., conducted the experiments, recorded and analyzed the data and drafted the article; J.C.B., M.R.I., A.I., and U.A.N., suggested modifications, edited and approved the final manuscript.

\section{Conflicts of Interest}

The authors declare no conflicts of interest regarding the publication of this paper. 


\section{References}

[1] BBS (Bangladesh Bureau of Statistics) (2017) Statistical Year Book of Bangladesh. Stat. Div., Ministry of Planning, Government of the People's Republic of Bangladesh, Dhaka.

[2] Haque, M.M., Saleque, M.A., Shah, A.L., Biswas, J.C. and Kim, P.J. (2015) Long-Term Effect of Sulfur and Zinc Fertilization on Rice Productivity and $\mathrm{Nu}$ trient Efficiency in Double Rice Cropping Paddy in Bangladesh. Communications in Soil Science and Plant Analysis, 1-11. https://doi.org/10.1080/00103624.2015.1104333

[3] Bhuiyan, N.I., Paul, D.N.R. and Jabber, M.A. (2002) Feeding the Extra Millions by 2025: Challenges for Rice Research and Extension in Bangladesh. Proceedings of the National Workshop on Rice Research and Extension, Gazipur, 29-31 January 2002.

[4] Kabir, M.S., Salam, M.U., Chowdhury, A., Rahman, N.M.F., Iftekharuddaula, K.M., Rahman, M.S., Rashid, M.H., Dipti, S.S., Islam, A., Latif, M.A., Islam, A.K.M.S., Hossain, M.M., Nessa, B., Ansari, T.H., Ali, M.A. and Biswas, J.K. (2015) Rice Vision for Bangladesh: 2050 and Beyond. Bangladesh Rice Journal, 19, 1-18.

[5] Sawaneh, M., Latif, I.A. and Abdullah, A.M. (2013) Total Factor Productivity of Rice Farming in Selected Southeast Asian Countries. Proceeding of the International Conference on Social Science Research, Penang, 4-5 June 2013.

[6] Ullah Sarkar, M.I., Rahman, M.M., Rahman, M., Naher, U.A. and Ahmed, M.N. (2016) Soil Test Based Inorganic Fertilizer and Integrated Plant Nutrition System for Rice (Oryza sativa L.) Cultivation in Inceptisols of Bangladesh. The Agriculturists, 14, 33-42. https://doi.org/10.3329/agric.v14i1.29098

[7] Shah, A.L., Islam, M.R., Haque, M.M., Ishaque, M. and Miah, M.A.M. (2008) Efficacy of Major Nutrients in Rice Production. Bangladesh Journal of Agricultural Research, 33, 639-645. https://doi.org/10.3329/bjar.v33i4.2308

[8] Dobermann, A.D., Dawe, R., Roher, P. and Cassman, K.G. (2000) Reversal of Rice Yield Decline in a Long-Term Continuous Cropping Experiment. Agronomy Journal, 92, 633-643. https://doi.org/10.2134/agronj2000.924633x

[9] Saleque, M.A., Abedin, M.J., Bhuiyan, N.I., Zaman, S.K. and Panaullah, G.M. (2004) Long-Term Effects of Inorganic and Organic Fertilizer Sources on Yield and Nutrient Accumulation of Lowland Rice. Field Crops Research, 86, 53-65. https://doi.org/10.1016/S0378-4290(03)00119-9

[10] Sihi, D., Dari, B., Sharma, D.K., Pathak, H., Nain, L. and Sharma, O.P. (2017) Evaluation of Soil Health in Organic vs. Conventional Farming of Basmati Rice in North India. Journal of Plant Nutrition and Soil Science, 180, 389-406.

[11] Shah, A.L., Islam, M.R., Haque, M.M., Ishaque, M.M. and Miah, A.M. (2008) Efficacy of Major Nutrients in Rice Production. Bangladesh Journal of Agricultural Research, 33, 639-645. https://doi.org/10.3329/bjar.v33i4.2308

[12] Haque, M.M., Kim, S.Y., Pramanik, P., Kim, G.Y. and Kim, P.J. (2013) Optimum Application Level of Winter Cover Crop Biomass as Green Manure under Considering Methane Emission and Rice Productivity in Paddy Soil. Biology and Fertility of Soils, 49, 487-493. https://doi.org/10.1007/s00374-012-0766-2

[13] Dey, S.K. and NarasingaRao, C.H. (1989) Influence of Nutrient Deficiency on Photosynthesis and Productivity in Early Rice. Oryza, 26, 317-319.

[14] Kumar, A. and Yavdav, D.S. (2005) Influence of Continuous Cropping and Fertilization on Nutrient Availability and Productivity of Alluvial Soil. Journal of the Indian Society of Soil Science, 55, 194-198.

[15] Panaullah, G.M., Timsina, J., Saleque, M.A., Ishaque, M., Pathan, A.B.M.B.U., 
Connor, D.J., Saha, P.K., Quayyum, M.A., Humphreys, E. and Meisner, C.A. (2006) Nutrient Uptake and Apparent Balances for Rice-Wheat Sequences. III. Potassium. Journal of Plant Nutrition, 29, 173-187. https://doi.org/10.1080/01904160500416554

[16] Nelson, D.W. and Sommers, L.E. (1996) Total Carbon, Organic Carbon and Organic Matter. In: Sparks, D.L., et al., Eds., Methods of Soil Analysis, Part 3, Chemical Analysis, Agron. Monogr. No. 9, ASA Inc., Madison.

[17] Page, A.L., Miller, R.H. and Keeny, D.R. (1982) Methods of Soil Analysis. Part 2. Chemical and Microbiological Properties. Agron. Monogr. No. 9, ASA Inc., Madison.

[18] Fox, R.L., Olson, R.A. and Rhoades, H.F. (1964) Evaluating the Sulfur Status of Soil by Plant and Soil Tests. Soil Science Society of America, Proceedings, 28, 243-246. https://doi.org/10.2136/sssaj1964.03615995002800020034x

[19] Olson, R.V. and Ellis Jr., R. (1982) Iron. In: Page, A.L., et al., Eds., Methods of Soil Analysis, Part 2, Chemical and Microbiological Properties, Agron. Monogr. No. 9, ASA Inc., Madison.

[20] SAS Institute (1995) System for Windows Release 6.11. SAS Institute, Cary.

[21] Biswas, J.C., Islam, M.R., Biswas, S.R. and Islam, M.J. (2004) Crop Productivity at Farmers Fields: Options for Soil Test Based Fertilizer Use and Cropping Patterns. Bangladesh Agronomy Journal, 10, 31-41.

[22] Yadav, R.L., Yadav, D.S., Singh, R.M. and Kumar, A. (1998) Longterm Effects of Inorganic Fertilizer Inputs on Crop Productivity in a Rice-Wheat Cropping System. Nutrient Cycling in Agroecosystems, 51, 193-200. https://doi.org/10.1023/A:1009744719420

[23] Haque, M.M., Saleque, M.A. and Shah, A.L. (2015) Effect of Long-Term Fertilization on Rice Productivity and Nutrient Efficiency under Double Cropping System.

[24] Cassman, K.G. and Pingali, P.L. (1995) Extrapolating Trends from Long-Term Experiments to Farmer's Field. The Case of Irrigated Rice System in Asia. In: Agricultural Sustainability. Economics, Environmental and Statistical Considerations, John Wiley and Sons, New York, 63-84.

[25] Shah, A.L., Haque, M.M. and Zaman, S.K. (2008) Implications of Long-Term Missing Element Trial: Efficacy of Potassium Fertilizer to Increase Rice Yield. Bangladesh Rice Journal, 14, 55-59.

[26] Saha, M.N., Saha, A.R., Mandal, B.C. and Ray, P.K. (2000) Effects of Long-Term Jute-Rice-Wheat Cropping System on Crop Yields and Soil Fertility. In: Abrol, I.P., Bronson, K.F., Duxbury, J.M. and Gupta, R.K., Eds., Long-Term Soil Fertility Experiments with Rice-Wheat Rotations in South Asia, Rice-Wheat Consortium Paper Series 6, Rice-Wheat Consortium for the Indo-Gangetic Plains, New Delhi, 94-104.

[27] Subramanian, S.K. and Kumaraswamy, K. (1989) Effect of Continuous Cropping and Fertilization on Chemical Properties of Soil. Journal of the Indian Society of Soil Science, 37, 171-173.

[28] Saha, P.K., Islam, R., Miah, M.A.M. and Bhuiyan, N.I. (2003) Integrated Nutrient Management for Rice Production in Old Meghna Estuarine Floodplain. Bangladesh Journal of Agricultural Research, 28, 521-531.

[29] Biswas, J.C., Haque, M.M., Akter, M., Hossain, A.T.M.S., Khan, F.H., Baki, M.Z.I., Sarker, A.B.S. and Islam, M.R. (2018) Element Composition of the Atmospheric Depositions in Bangladesh. Journal of Environmental Protection, 9, 948-956. https://doi.org/10.4236/jep.2018.99059

[30] Panday, S.N. and Sinha, B.K. (1990) Plant Physiology. Vikas Publishing House Pvt. Ltd., 2nd Revised Edition, New Delhi. 